\title{
Pemberdayaan Masyarakat Melalui Pelatihan Sampah Menjadi Nilai Ekonomis dan Bantuan Teknis Di Kelurahan Tungkal II Kabupaten Tanjung Jabung Barat
}

\author{
Nurhayani, Dearmi Artis, Parmadi, Rosmeli, Novita Ekasari \\ Email: nurhayani@unja.ac.id
}

\begin{abstract}
ABSTRAK
Kegiatan pemberdayaan masyarakat melalui pelatihan sampah menjadi nilai ekonomis dan bantuan teknis Di Kelurahan Tungkal II Kabupaten Tanjung Jabung Barat dilaksanakan selama 1 hari pada hari Sabtu tanggal 12 September 2020. Pengabdian dilakukan di rumah salah satu warga di Jalan Kalimantan di Kelurahan Tungkal II diikuti oleh 12 peserta. Karena keterbatasan waktu kegiatan awal pelatihan sampah menjadi nilai ekonomis di lakukan dengan pelatihan pemilahan jenis sampah. Dari hasil kegiatan pihak mitra pengabdian dapat meningkatkan kesadaran masyarakat tentang kebesihan dan dapat juga memilah jenis sampah sesuai dengan kelompoknya masing-masing serta mengaplikasikan komposter yang akan menghasilkan pupuk cair dan padat yang dapat dimanfaatkan sebagai pupuk tanaman.
\end{abstract}

Kata Kunci: Pemberdayaan Masyarakat, sampah

\section{PENDAHULUAN}

Kelurahan Tungkal II merupakan kelurahan yang terdapat di Kecamatan Tungkal Ilir kabupaten Tanjung Jabung Barat Provinsi Jambi dengan luas wilayahnya seluas kurang lebih 1.652 Ha yang memiliki jumlah penduduk sebanyak 12.004 jiwa pada tahun 2020. Jumlah penduduk yang cukup ini akan menambah jumlah sampah di daerah tersebut. Sampah adalah adalah sisa atau barang buangan yang sudah tidak digunakan dan di pakai lagi oleh pemiliknya. Sampah secara umum di bagi menjadi dua yaitu sampah organik dan anorganik (Taufik, 2015). Total produksi sampah masyarakat dalam Kota Kuala tungkal mencapai 54 ton per hari. Dengan perhitungan satu rumah tangga menyumbang sebanyak $0,2 \mathrm{~kg}$ sampah per hari. Dari totaol 54 ton hanya terhitung 42 ton sehari yang masuk ke TPA (Tempat Pembuangan Akhir), sisanya dibuang ke laut atau ke sungai dan dibiarkan menumpuk di bawah kolong rumah.

Beberapa program sudah dilakukan oleh pemerintah setempat, namun masih menemukan kendala, antara lain diadakannya sosialisasi tentang sampah sesuai dengan Perda No 7 tahun 2018 tentang pencegahan dan peningkatan kualitas terhadap perumahan dan pemukiman kumuh dengan beberapa upaya salah satunya adalah dengan membudayakan membuang sampah pada tempatnya dan memisahkan sampah organik dan non organik namun pada kenyataannya masih banyak sampah yang dibuang sembarangan dan sampah banyak menumpuk yang menyebabkan lingkungan menjadi kotor dan kumuh. Program lain yang pernah dilakukan adalah dengan membuat 1000 tong sampah, namun ada kendala yaitu banyaknya tong sampah yang hilang.

Permasalahan mitra secara tekhnis adalah sampah yang berasal dari rumah tangga tidak optimal pemanfaatannya karena tidak berfungsinya komposer yang ada. Komposer yang diperoleh kelurahan dari bantuan Program pemerintah setempat yang dilakukan sekitar 7 tahun yang lalu sudah tidak ada. Berdasarkan pertemuan dengan salah satu pegawai yang bekerja di kantor Keluarahan Tungkal II diharapakan solusi mengatasi masalah dengan memberikan alat pengolah sampah (komposter). Permasalahan pada aspek sumberdaya manusia adalah belum 
adanya pelatihan untuk menambah ketrampilan masyarakat membuat kerajinan yang bahannya dari sampah rumah tangga. dengan melaksanakan pelatihan tentang pengolahan sampah plastik menjadi barang yang bernilai ekonomis.

Pengolahan tentang sampah harus melibatkan seluruh lapisan masyarakat, karena faktor penyebab banyaknya sampah salah satunya adalah dari kurangnya pengetahuan masyarakat mengenai sampah. Sehingga masyarakat lebih memilih membuang sampah dari pada mengolahnya. Dengan pemberdayaan masyarakat kelurahan Tungkal II ini dapat memberikan pengetahuan kepada masyarakat. Pemanfaatan sampah dapat diolah menjadi banyak produk seperti untuk sampah anorganik misalnya sampah plastik dapat dibuat tas, souvenir dan lainlain. Dan untuk sampah organik dapat dibuat pupuk kompos. Hal ini penting dilakukan karena selain dapat mengurangi sampah yang ada juga dijadikan sebagai kerajinan yang bernilai ekonomis.

\section{Permasalahan Mitra}

Perkembangan sampah yang semakin banyak salah satunya dengan mingkatnya jumlah aktivitas penduduk dan diiringi dengan kurangnya kepedulian masyarakat terhadap pengelolaan sampah. Banyaknya volume sampah di Kelurahan Tungkal II Kecamatan Tungkal Ilir Membuat permasalah sampah di daerah tersebut belum terselesaikan dengan baik. Berdasarkan pendekatan awal dengan mitra sehingga dapat di susun prioritas permasalahan mitra dan rencana solusinya sebagai berikut:

1. Permasalah mitra dalam pengolahan sampah organik menjadi pupuk kompos padat dan cair. Komposter yang ada yang diperoleh dari bantuan pemerintah setempat tidak berfungsi lagi.

2. Permasalahan mitra dalam memilah dan mengolah sampah terutama yang plastik, botol dan lainnya dan kurangnya ketrampilan masyarakat dalam membuat kerjinan yang bahannya berasal dari sampah rumah tangga sehingga menjadi barang ekonomis

\section{TINJAUAN LITERATUR}

UU No 18 Tahun 2008 tentang Pengelolaan Sampah menyebutkan bahwa sampah adalah sisa kegiatan sehari-hari masyarakat atau proses alam yang berbentuk padat atau semi padat berupa zat organik atau anorganik bersifat dapat terurai atau tidak dapat terurai yang dianggap sudah tidak berguna lagi dan dibuang ke lingkungan. Berdasarkan definisi ini maka sampah dapat berupa sampah yang mudah membusuk seperti sampah dapur, daun-daun kering, kotoran hewan dan sejenisnya. Sedangkan sampah yang tidak mudah terurai atau membusuk seperti sampah plastik, logam, gelas, karet dan lain-lain

Peraturan Pemerintah No 81 tahun 2012 mengamanatkan perlunya perubahan paradigma yang mendasar dalam pengelolaan sampah yaitu dari paradigma kumpul-angkutbuang menjadi pengolahan yang bertumpu pada pengurangan sampah dan penanganan sampah. Kegiatan pengurangan sampah bermakna agar seluruh lapisan masyarakat, baik pemerintah, dunia usaha maupun masyarakat luas melaksanakan pembatasan timbulan sampah, pendauran ulang dan pemanfaatan kembali sampah atau yang lebih dikenal dengan konsep 3R. Pengertian pengelolaan sampah 3R secara umum adalah upaya pengurangan pembuangan sampah, melalui program menggunakan kembali (reuse), mengurangi (reduce), dan mendaur ulang (recycle). Konsep tersebut dapat dijabarkan sebagai berikut: 1. Reuse (menggunakan kembali), yaitu penggunaan kembali sampah secara langsung baik untuk fungsi yang sama maupun fungsi lain. Contoh yang dapat dilakukan di rumah tangga misalnya penggunaan kembali wadah bekas botol madu untuk wadah pernak-pernik, kaleng cat untuk tempat sampah, botol plastik untuk 
pot bunga dan sebagainya. 2. Reduce (mengurangi), yaitu mengurangi segala sesuatu yang menyebabkan timbulnya sampah. Hal ini dapat dilakukan misalnya dengan menggunakan kantong yang tahan lama untuk belanja kebutuhan sehari-hari, menggunakan produk yang bisa diisi ulang, mengurangi pemakaian bahan sekali pakai seperti tisue dengan serbet atau sapu tangan, membawa wadah makan atau minum sendiri dan lain-lain. 3. Recycle (daur ulang), yaitu memanfaatkan kembali sampah setelah mengalami proses pengolahan. Hal yang dapat dikerjakan untuk konsep ini dalam skala rumah tangga diantaranya selalu memilih produk atau kemasan yang memiliki tanda bisa atau mudah didaur ulang, membuat kompos dari sampah organik yang dihasilkan, membuat sampah kaleng menjadi barang lain yang lebih bermanfaat.

Peran Bank Sampah menjadi penting dengan terbitnya Peraturan Pemerintah (PP)

Nomor 81 Tahun 2012 tentang Pengelolaan Sampah Rumah Tangga dan Sampah Sejenis Sampah Rumah Tangga. PP tersebut mengatur tentang kewajiban produsen untuk melakukan kegiatan 3R dengan cara menghasilkan produk yang menggunakan kemasan yang mudah diurai oleh proses alam; yang menimbulkan sampah sesedikit mungkin; menggunakan bahan baku produksi yang dapat didaur ulang dan diguna ulang; dan/atau menarik kembali sampah dari produk dan kemasan produk untuk didaur ulang dan diguna ulang. Dengan adanya Bank Sampah, maka produsen dapat melakukan kerja sama dengan Bank Sampah yang ada agar dapat mengolah sampah dari produk yang dihasilkannya sesuai dengan amanat PP tersebut.

Bank sampah memiliki manfaat yang dapat dirasakan oleh masyarakat yaitu dari pembuatan kompos dapat meningkatkan produksinya dan dapat digunakan untuk pertanian yang ada di sekitar daerah selain itu dari kegiatan bank sampah masyarakat dapat berprilaku bersih dengan tidak membuang sampah sembarang dan terbiasa memafaatkan sampah untuk hal yang lebih bermanfaat Octavia dkk (2015). Andrani (2014) juga mengatakan bahwa pengelolaan sampah akan melindungi lingkungan dan membuat masyarakat bertambah sehat. Saputro (2015); Lestari, (2018) mengungkapkan bahwa pemilahan sampah sesuai dengan jenisnya akan memudahkan untuk proses daur ulang dan selanjutnya dapat dimanfaatkan pembuatan pupuk kompos pembuatan biogas dan pembuatan kertas daun methanica.

Suhastyo (2017) menjelaskan bahwa pemanfaatan kompos selama ini belum terlalu dipahami oleh masyarakat. Padahal kompos mempunyai banyak manfaat seperti: memperbaiki struktur tanah berlempung sehingga menjadi ringan; tanah tidak berderai karena daya ikat tanah berpasir diperbanyak; menambah daya ikat tanah terhadap air dan unsur-unsur hara tanah; memperbaiki drainase dan tata udara dalam tanah dan aktivitas mikroorganisme yang merugikan dapat dikendalikan.

\section{METODE PELAKSANAAN}

\section{Metode Pengabdian}

Metode pelaksanaan pengabdian yang dilakukan adalah dengan cara sebagai berikut:

1). Penyampian teori dan konsep-konsep

Penyampaian materi yang sangat prinsip dan penting akan diberikan oleh tim pengabdian dan narasumber. Materi yang diberikan meliputi: menjelaskan tujuan dari pengabdian serta pekerjaan-pekerjaan yang akan dilakukan serta memberikan pemahaman tentang konsepkonsep yang berhubungan dengan pengabdian. Dalam kegiatan penyuluhan diberikan penjelasan tentang pengelolaan sampah, jiwa wirausaha dan pengembangan kreativitas dan inovasi dalam menghasilkan produk olahan sampah yang bernilai ekonomis.

2). Pelatihan pemilahan sampah sesuai jenisnya, dilakukan denga cara memilah sampah yang sebelumnya telah di bawa oleh peserta. 
3). Pembuatan pupuk kompos dan pembautan barang bernilai ekonomis. Setelah dijelaskan mengenai materi pengabdian dari tim pengabdian masyarakat dan narasumber dari Bank sampah, selanjutnya adalah peserta akan melakukan latihan langsung untuk penggunaan komposter dan pelatihan membuat barang yang bernilai ekonomis dengan bahan dasar dari sampah rumah tangga.

\section{HASIL DAN PEMBAHASAN}

Pengabdian dilakukan di rumah salah satu warga di Jalan Kalimantan di Kelurahan Tungkal II Kabupaten Tanjung Jabung Barat, diikuti oleh 12 peserta. Hasil kegiatan pengabdian kepada mayarakat tentang pemberdayaan masyarakat melalui pelatihan sampah menjadi nilai ekonomis dan bantuan teknis antara lain adalah berupa pengetahuan tentang sampah dan permasalahannya, pengelolaan sampah berdasarkan konsep $3 \mathrm{R}$, pengetahuan peserta tentang jenis sampah dan pengelompokkannya serta ketrampilan peserta dalam membuat pupuk kompos. Dengan adanya pengabdian maka:

\section{Terdapat peningkatan kesadaran masyarakat dalam mengelola sampah}

Peserta pengabdian memahami pengelompokkan jenis sampah dan direncanakan akan dibentuk kelompok-kelompok kecil sebagai awal dari proses pengumpulan sampah rumah tangga. Peserta pengabdian sangat mendukung kegiatan ini untuk meningkatkan kepedulian masyarakat terhadap kebersihan Meski selama ini sudah terpasang imbauan tidak buang sampah sembarangan, tetapi hal itu tidak efektif karena masyarakat masih belum sadar dalam menjaga kebersihan lingkungannya. Tumpukan sampah rumah tangga, mulai dari plastik bekas makanan dan popok bayi yang masih berserakan mengotori disekitar rumah warga dan pinggir jalan dan di saat musim hujan akan tergenang oleh air. Selanjutnya setelah di lakukan pemilahan barang-barang bekas sesuai dengan kelompoknya masing-masing maka akan dapat di bentuk bank sampah. Bank sampah merupakan wadah untuk menampung sampah agar tidak hanya terbuang sia-sia tetapi juga ditukar dengan manfaat daur ulang dan uang.

Disaat pengabdian dilaksanakan salah satu peserta tim pengabdian merupakan direktur Bank Sampah Bangkitku, sehingga peserta pengabidan dapat bertanya langsung dan sangat bersemangat berkonsultasi tentang tahapan-tahapan pembentukan bank sampah. Bank sampah juga dapat dijadikan solusi untuk mencapai pemukiman yang bersih dan nyaman bagi warganya. Dengan pola ini maka warga selain menjadi disiplin dalam mengelola sampah juga mendapatkan tambahan pemasukan dari sampah-sampah yang dikumpulkan.

\section{Dapat Menggunakan Komposter (Alat Pembuat Kompos)}

Pemakaian komposter ini sangat sederhana sekali. Peserta dapat mengaplikasikan penggunaan komposter yang diberikan. Pengolahan sampah organik yang berasal dari sampah rumah tanggga berupa sisa makanan dapat dimasukan ke dalam komposter yang akan menghasilkan pupuk organik cair dan pupuk padat (kompos). Pupuk cair dikeluarkan melalui kran bagian bawah komposter dan dapat dimanfaatkan sebagai pupuk tanaman dengan menyiramkan pada tanah di sekitar tanaman, bukan pada batang tanaman, sedangkan pupuk padat (kompos) yang diperoleh dari dikering anginkan dahulu sebelum digunakan. Beberapa peserta pengabdian merupakan pedagang di pasar terdekat yang dapat mengambil sampah - sampah sayuran misalnya kol, sayur bayam, kangkung timun dan lain-lain yang sudah mulai busuk atau tidak laku dijual. Pengisian komposter secara berkelompok akan memudahkan pengisisan, karena jika hanya satu keluarga sayuran sisa tidak banyak, sehingga komposter digunakan untuk beberapa rumah tangga. 
Pemberian bantuan komposter terbatas sehingga peserta membentuk kelompokkelompok kecil untuk dapat mengisi secara optimal komposter tersebut. Dengan adanya kelompok-kelompok kecil ini akan mengguatkan kesadaran masyarakat sekitar agar ikut berperan serta dalam mengurangi jumlah sampah dilingkungannya.

\section{KESIMPULAN DAN SARAN}

\section{Kesimpulan}

Kegiatan pemberdayaan masyarakat melalui pelatihan sampah menjadi nilai ekonomis dan bantuan teknis Di Kelurahan Tungkal II Kabupaten Tanjung Jabung Barat yang dilaksanakan selama 1 hari pada hari Sabtu tanggal 12 September 2020 berjalan dengan lancar. Tim pengabdian dan peserta pengbdian saling bertukar pikiran dan penjelasan tentang masalah sampah. Dari hasil kegiatan pihak mitra pengabdian dapat meningkatkan kesadaran masyarakat tentang kebesihan dan dapat juga memilah jenis sampah sesuai dengan kelompoknya masingmasing serta mengaplikasikan komposter akan menghasilkan pupuk cair dan padat.

\section{Saran}

Saran Sebaiknya kegiatan pengabdian ini dapat dilaksanakan kembali dengan peserta pengabdian yang lebih banyak dan diperlukan kegiatan PPM lanjutan sebagai tindak lanjut pencapaian hasil pengabdian saat ini yaitu adalah pembentukan bank sampah sehingga tidak hanya memilah tetapi juga dapat di salurkan barang yang telah di pilah.

\section{DAFTAR PUSTAKA}

Andarani, A dan Naohiro Goto (2014). Potential e-waste generated from households in Indonesia using material flow analysis. Springer Japan No 16: 306-320.

Lestari, Novi dan Dicky. (2018). ibM Bank Sampah Desa Mojorejo Kota Batu. Jurnal Pengabdian Kepada Masyarakat, Volume 1 Nomor 1, Hal, 23-27.

Octavia, Ade dkk. (2015). Pemberdayaan Masyarakat Melalui Optimalisasi Program Bank Sampah dengan Bantuan Tekhnis dan Manajemen Usaha pada KSM Aneka Limbah dan KSM Maidanul Ula Kota Jambi. Jurnal Pengabdian pada Masyarakat, Volume 30 Nomor 3, Hal. 40-48

Saputro, Yuso dkk. (2015). Pengelolaan Sampah Berbasis Masyarakat Melalui Bank Sampah. Indonesian Journal of Conservation, Volume 4 Nomor 1, Hal 83-94.

Suhastiyo, Arum. (2017). Pemberdayaan Masyarakat Melalui Pelatihan Pembuatan Pupuk Kompos. Jurnal Pengabdian dan Pemberdayaan Masyarakat, Volume 1 Nomor 2, Hal. 63-68.

Taufiq, A, Maulana, M, F. (2015). Sosialisasi Sampah Organik Dan Non Organik Serta Pelatihan Kreasi Sampah. Seri Pengabdian Masyarakat Jurnal Inovasi Dan Kewirausahaan Volume 4 No. 1, Januari 2015 Halaman 68-73. 